\title{
Characterization and ecological implication of eelgrass life history strategies near the species' southern limit in the western North Atlantic
}

\author{
Jessie C. Jarvis ${ }^{1,3, *}$, Kenneth A. Moore ${ }^{1}$, W. Judson Kenworthy ${ }^{2}$ \\ ${ }^{1}$ Virginia Institute of Marine Science, School of Marine Science, College of William and Mary, Gloucester Point, \\ Virginia 23062, USA \\ ${ }^{2}$ Center for Coastal Fisheries and Habitat Research, NCCOS, NOS, NOAA, 101 Pivers Island Road, Beaufort, \\ North Carolina 28516, USA \\ ${ }^{3}$ Present address: The Richard Stockton College of New Jersey, Galloway, New Jersey 08205-9441, USA
}

\begin{abstract}
Eelgrass Zostera marina L. populations located near the species southern limit in the western North Atlantic were assessed monthly from July 2007 through November 2008. We identified (1) dominant life history strategies and local environmental conditions in southern $Z$. marina populations, (2) quantified differences in reproductive phenology between populations and different local environmental conditions, and (3) compared reproductive strategies to established annual and perennial life history paradigms. Observed populations expressed both life history strategies with one $Z$. marina population completely losing aboveground biomass and reestablishing from seeds (annual model) while another population retained aboveground biomass throughout the year (perennial model). A third life history strategy, characterized here as a mixed-annual population, was also observed after some seedlings were found to reproduce both sexually and asexually during their first year of growth thereby not conforming to any currently established life history paradigm. Development of multiple life history strategies within this region may be in response to stressful summer water temperatures associated with the southern edge of the species' range. We suggest that neither annual nor perennial life history strategies always provide a superior mechanism for population persistence as perennial populations can be susceptible to multiple consecutive years of stress, and annual populations are unable to fully exploit available resources throughout much of the year. The mixed-annual strategy observed here represents another possible life history model which may provide the mechanism necessary for Z. marina populations to persist during times of environmental transition.
\end{abstract}

KEY WORDS: Zostera marina $\cdot$ Life-history $\cdot$ Annual $\cdot$ Perennial $\cdot$ Seed bank $\cdot$ Biomass Resale or republication not permitted without written consent of the publisher

\section{INTRODUCTION}

Eelgrass Zostera marina is circumglobally distributed, ranging in latitude from warm temperate waters to near arctic conditions (Setchell 1929, den Hartog 1970, Green \& Short 2003, Moore \& Short 2006). Z. marina displays a tolerance to wide ranging temperature and salinity conditions and has distinct life history strategies allowing the species to exploit intertidal to subtidal zones and from open ocean environments to the interior of brackish water estuaries (Setchell 1929, Harrison 1993, Meling-López \& IbarraObando 1999, van Katwijk \& Wijgergangs 2004).

The most common life-history strategy observed in Zostera marina populations is the perennial form where plants persist for several years primarily through asexual growth (den Hartog 1970; Tomlinson 1974; Lincoln et al. 1990). Perennial Z. marina 
populations have also been documented to express behavior similar to the biennial life history model (Setchell, 1929). After germinating, seedling growth in biennial populations occurred via clonal expansion only and flowering stem development and fruiting were not observed until after a period of 1 to $2 \mathrm{yr}$ of growth (Setchell 1929; Thayer et al. 1984). More recently an annual life history strategy has been described for $Z$. marina populations, where mature plants consist of reproductive (flowering) shoots only and all plants complete their life cycle (seeds germinate, flower, produce seeds) and die within 12 mo (Keddy \& Patriquin, 1978, Gagnon et al. 1980, De Cock 1981, Harlin et al. 1982, Phillips et al. 1983a, Robertson \& Mann 1984, Santamaría-Gallegos et al. 2000).

Although they have been documented throughout the species' geographic distribution, annual forms of Zostera marina are primarily found in areas characterized by stressful environmental conditions such as ice scour (Robertson \& Mann 1984), extreme temperatures (Phillips et al. 1983a, Santamaría-Gallegos et al. 2000), and interactions between physical disturbances such as grazers and strong storms (van Lent \& Verschuure 1994). Phillips et al. (1983a) suggested that the large annual population in the Gulf of California may have developed in response to recurring high summer water temperatures experienced at the southern limit of the species distribution. At Bahia Kino, where the most extensive $Z$. marina meadows in the Gulf of California occur, water temperatures reach $32^{\circ} \mathrm{C}$ in July, resulting in $100 \%$ mortality of $Z$. marina shoots (Phillips \& Backman 1983). In this meadow, the entire population is sustained year to year by the production of seeds from annual plants (Meling-López \& Ibarra-Obando 1999).

In the western Atlantic, the southern limit of Zostera marina distribution occurs in North Carolina where there is an estimated 80937 ha of submerged aquatic vegetation including $Z$. marina, widgeon grass Ruppia maritima and shoal grass Halodule wrightii (Street et al. 2005). With the warm climate and proximity of the Gulf Stream, temperatures in North Carolina coastal waters reach $\geq 30^{\circ} \mathrm{C}$ in summer and mortality of $Z$. marina is high during this period (Thayer et al. 1984). Z. marina dominated meadows lose most of their aboveground biomass by early fall in response to the high thermal stress experienced at this southerly latitude (Kenworthy 1981, Thayer et al. 1984). Flowering frequency in the population is also relatively high (11 to $32 \%$; Thayer et al. 1984, Fonseca et al. 1985) and seed- lings are ubiquitous throughout the system (authors' pers. obs.). Long-term observations in seagrass meadows in Back and Core Sounds in Carteret County, North Carolina suggest that there are both perennial and annual populations (K. Kenworthy pers. obs.). Recent observations (authors' pers. obs.) in a well studied site in the Newport River Estuary (Thayer et al. 1977, 1984, Penhale 1977) indicated that a formerly perennial $Z$. marina meadow was expressing characteristics of an annual population: $100 \%$ shoot mortality was observed in the early fall (October to November) of 2004, 2005, and 2006, yet each year the meadow was reestablished by seedlings (authors' pers. obs.). Although the occurrence of annual populations at the southern limit in the Atlantic does not seem as prevalent as in the Pacific populations in the Gulf of California, given the similarities of thermal stressors between these geographical regions there is reason to predict that $Z$. marina populations in North Carolina should benefit from a strategy with a higher proportion of sexual reproduction.

It is the goal of this paper to (1) investigate dominant life history strategies and local environmental conditions in southern western Atlantic Zostera marina populations; (2) quantify differences in reproductive phenology (biomass and density of vegetative and reproductive shoots, total seed production, total seed bank density, and viable seed bank density) between observed life history strategies; and (3) compare reproductive strategies within these thermally stressed populations to established life history paradigms.

\section{MATERIALS AND METHODS}

\section{Study sites}

We selected 2 sites in North Carolina for our study (Fig. 1). Phillips Island ( $\mathrm{NC} 1 ; 34^{\circ} 43^{\prime} \mathrm{N}, 76^{\circ} 41^{\prime} \mathrm{W}$ ) is located on a shallow small semi-enclosed shelf in the Newport River Estuary in Carteret County. The seagrass bed is dominated by Zostera marina with small isolated patches of Ruppia maritima. Morgans Island ( $\left.\mathrm{NC2}, 34^{\circ} 66^{\prime} \mathrm{N}, 76^{\circ} 52^{\prime} \mathrm{W}\right)$, located $\sim 14 \mathrm{~km}$ southeast of Phillips Island in Back Sound on a shallow open shelf, is a mixed bed of $Z$. marina and Halodule wrightii with a minor amount of $R$. maritima. Both sites are shallow, with mean lower low water (MLLW) depths $<0.25$ to $0.5 \mathrm{~m}$ (Penhale 1977, Thayer et al. 1977). Within each site a $30 \times 30 \mathrm{~m}$ area was delineated for sampling. 


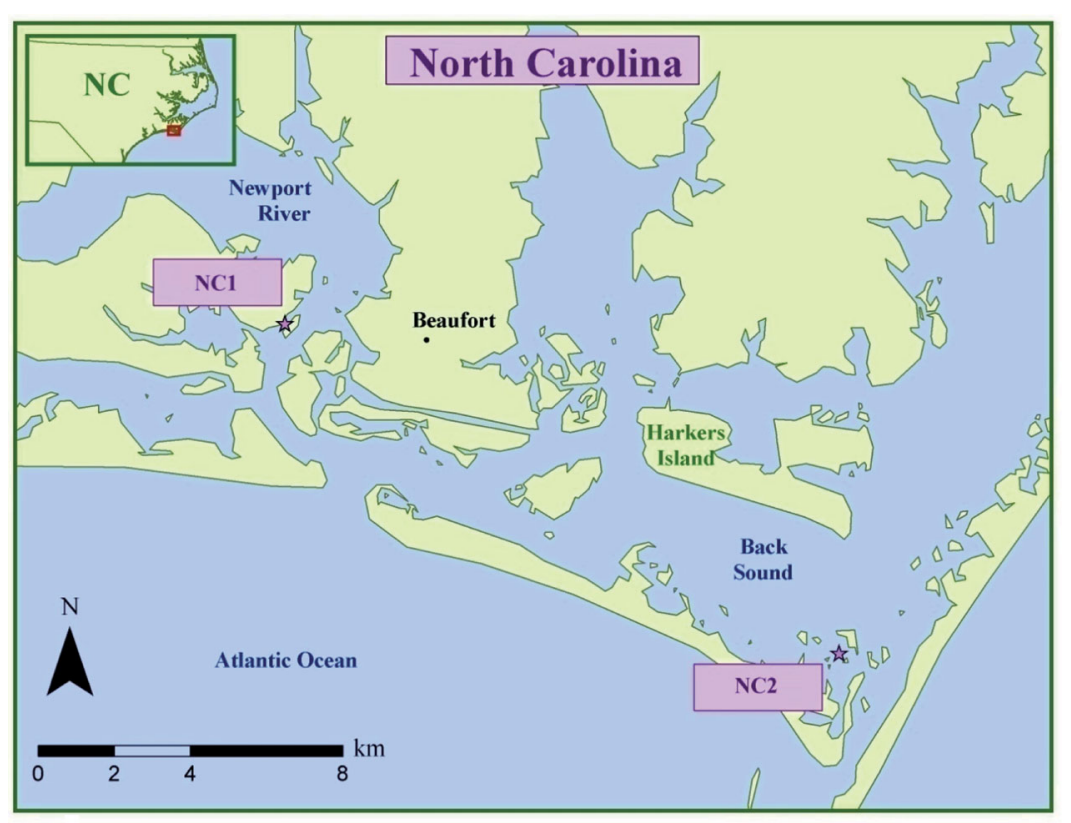

Fig. 1. Sampling sites ( 1 ; NC1, NC2) for study of eelgrass Zostera marina life history strategies in North Carolina

\section{Study site characterization}

Bottom water temperature $\left({ }^{\circ} \mathrm{C}\right)$ was recorded at each site every $15 \mathrm{~min}$ throughout the study period with 3 HOBOware Pro (Onset Computer) water temperature sensors deployed on the sediment surface. Salinity (PSU) and dissolved oxygen ( $\mathrm{DO} ; \mathrm{mg} \mathrm{l}^{-1}$ ) were measured monthly from August 2007 to October 2008 with a Yellow Spring Instruments model 650 sonde. During each site visit, three $500 \mathrm{ml}$ water samples were collected by hand, filtered (Gelman Supor, $0.45 \mu \mathrm{m})$, and frozen until analyzed for dissolved inorganic nitrogen (DIN; $\mathrm{NO}_{\mathrm{x}}, \mathrm{NH}_{4}{ }^{+}$) and dissolved inorganic phosphorus (DIP; $\mathrm{PO}_{4}{ }^{3-}$ ) with a Lachat Instruments auto analyzer (Liao 2002, Knepel \& Bogren 2002, Smith \& Bogren 2002). Water samples were also filtered and analyzed for chlorophyll $a$ (Strickland \& Parsons 1972) and total suspended solids (TSS). TSS was quantified from a well-mixed sample of known volume. The sample was filtered through a GF/F filter and the residue retained on the filter was dried to constant weight at 103 to $105^{\circ} \mathrm{C}$ and reported as $\mathrm{mg} \mathrm{l}^{-1}$.

At each site, 5 sediment cores $(10.4 \mathrm{~cm}$ diameter, $10 \mathrm{~cm}$ depth) were collected in July and December 2007 and in June and September 2008 to quantify organic content and sediment exchangeable nutrients. The upper $6 \mathrm{~cm}$ of the core was removed then subdivided. Percent organic matter was determined by drying a sediment sub-section at $60^{\circ} \mathrm{C}$ until a constant dry weight (DW) was reached. Samples were then weighed, combusted at $500^{\circ} \mathrm{C}$ for $5 \mathrm{~h}$, and weighed again. Percent organic matter was calculated as the difference in weights (Erftemeijer \& Koch 2001). Sediment exchangeable nutrients were extracted with a volume $\mathrm{KCl}(2 \mathrm{M})$ equal to twice the sediment volume, shaken on a rotary shaker for $1 \mathrm{~h}$ at room temperature, centrifuged $6 \mathrm{~min}$ at $1252 \mathrm{~g}$, filtered (Gelman Supor, $0.45 \mu \mathrm{m}$ ), and frozen in sterile Whirlpak ${ }^{\circledR}$ bags until analyzed. $\mathrm{NH}_{4}{ }^{+}$ was determined by the technique of Solorzano (1969). DIN $\left(\mathrm{NO}_{\mathrm{x}}\right)$ and DIP $\left(\mathrm{PO}_{4}{ }^{-3}\right)$ were determined on a Lachat Instruments auto analyzer (Liao 2002, Knepel \& Bogren 2002, Smith \& Bogren 2002). Additionally, in December 2007, percent sand, silt, and clay fractions were determined using a wet sieve method (Plumb 1981).

\section{Zostera marina characterization}

Five Zostera marina biomass cores $(22 \mathrm{~cm}$ diameter, $10 \mathrm{~cm}$ depth) were haphazardly collected monthly from both NC1 and NC2 from July 2007 through November 2008. Samples were sieved $(1.0 \mathrm{~cm}$ mesh) and washed clean of sediment in the field and all plant material was immediately transported back to the lab for processing. Biomass samples were sorted as reproductive shoots or non-reproductive shoots, and as surviving shoots or newly germinated seedlings. Reproductive shoots were defined as erect shoots that contained multiple rhipidia (De Cock 1981) and seedlings were determined by the presence of a seed coat or by a curved rhizome base (Setchell 1929, Taylor 1957b). Vegetative shoot density, reproductive shoot density, and the number of seeds per reproductive shoot were recorded. Vegetative shoots were then separated from the rhizome directly below the leaf sheath into aboveground and belowground biomass. Only living belowground biomass, whitish to light brown in color and attached to shoots, was processed. Belowground biomass was analyzed as total belowground biomass and not divided by reproductive state because some plants produced both vegetative and reproductive shoots. All biomass samples were dried at $60{ }^{\circ} \mathrm{C}$ to a constant weight. 


\section{Seed production and seed bank characteristics}

The maximum potential number of seeds produced at each site was calculated monthly from August 2007 through October 2008 as the product of the average number of seeds per reproductive shoot and the average number of reproductive shoots $\mathrm{m}^{-2}$ (van Lent \& Verschuure 1994). At each site, 5 sediment cores (4 cm diameter, $10 \mathrm{~cm}$ length) were collected in July and December 2007 and again in June, September, October and November 2008 to quantify total and viable sediment seed bank densities. All cores were wet-sieved $(0.5 \mathrm{~mm}$ mesh $)$ to separate the seeds; all seeds were counted and stored overnight in ambient seawater at $4^{\circ} \mathrm{C}$. The percentage of seeds retained within the sediment seed bank was quantified using the difference between the potential and measured seed bank densities.

Viability of all collected seeds was tested using tetrazolium staining (Lakon 1949, AOSA 1981, McFarland \& Shafer 2011). Seed embryos were removed from their seed coats and soaked in a $1 \%$ tetrazolium chloride solution for $24 \mathrm{~h}$ before examination on a dissecting scope at $10 \times$ magnification (Lakon 1949, AOSA 1981, Conacher et al. 1994). Seeds with a pink to brown stained cotyledon and axial hypocotyl were considered viable (Taylor 1957a, Harrison 1993). The percentage of viable seeds retained within the sediment seed bank was quantified compared to the total number of seeds collected in the seed bank at each site.

\section{Statistical analyses}

Water column TSS and sediment organic content and percentages of sand, silt and clay between sites and over time were analyzed separately with nonparametric statistics as the data were non-normally distributed (TSS and sediment organic content: Friedman's Chi Square; percent sand, silt and clay: Kruskal-Wallis and Kolmogorov-Smirnov Tests; SAS System for Windows). Monthly averaged water column temperature, salinity, DO, chlorophyll $a$, DIN, DIP and sediment DIN and DIP data were transformed when necessary and analyzed with repeated measures ANOVA to compare the effects of time, site and the interactions of these factors (Zar 1996).

Repeated measures ANOVA (PROC GLM; SAS System for Windows) was employed to test the effects of site and time on vegetative and reproductive shoot aboveground biomass, total belowground biomass, the proportion of reproductive shoots, and the proportion of viable seeds in the seed bank. Prior to analysis, data were transformed when necessary (biomass: square root transformation; proportion data: arcsine square root transformation), normality was confirmed, and homogeneity of variance was verified with Cochran's test (Zar 1996).

Differences in vegetative and reproductive shoot density, seed production, and seed bank density between sites were analyzed using negative binomial regression with time and site as factors (PROC GENMOD; SAS System for Windows) (Allison 1999). Negative binomial regression is a generalized form of Poisson regression which corrects for overdispersion in count data (Allison 1999). For all significant $(\mathrm{p}<0.05)$ model terms odds ratios were calculated using Wald chi square statistics (SAS System for Windows). Likelihood ratio tests for all parameter estimates were also calculated and compared to the Wald Chi Square Statistics (Allison 1999).

\section{RESULTS}

\section{Study site characterization}

Water column temperature varied significantly over time across both sites ( $p<0.001)$. Temperature was significantly greater at NC1 than NC2 during the spring and summer months ( $\mathrm{p}<0.001$; Fig. 2A). Daily temperature (mean $\pm \mathrm{SE}$ ) ranged from $7.2 \pm 0.1^{\circ} \mathrm{C}$ to $30.3 \pm 0.1^{\circ} \mathrm{C}$ at $\mathrm{NC} 1$ and from $4.8 \pm 0.1^{\circ} \mathrm{C}$ to $29.8 \pm$ $0.1^{\circ} \mathrm{C}$ at $\mathrm{NC} 2$. When comparing temperatures collected every 15 min across the summer months (June to August), temperatures were above $25^{\circ} \mathrm{C}$ for $88.5 \%$ and $93.1 \%$ of the time at NC1 and NC2, respectively (Fig. 3).

Water column DO and salinity varied significantly over time across both sites ( $p<0.001$ for all) and were significantly greater at NC2 than NC1 ( $p<0.001$; Fig. 2B, C). Water column chlorophyll a (chl a) was significantly greater at NC1 than NC2 $(p<0.001)$ and va ried significantly over time with highest values observed during summer months ( $p<0.001$; Fig. 2D). TSS followed a similar pattern to chlorophyll $a$ and was significantly greater at NC1 than NC2 $(\mathrm{p}<0.001$; Fig. 2E). Water column $\mathrm{NO}_{\mathrm{x}}$ and $\mathrm{NH}_{4}{ }^{+}$were similar between sites $\left(\mathrm{NO}_{\mathrm{x}} \mathrm{p}=0.369 ; \mathrm{NH}_{4}{ }^{+} \mathrm{p}=0.099\right)$ but were significantly different over time although no distinct seasonal patterns among years were evident $\left(\mathrm{NO}_{\mathrm{x}} \mathrm{p}=0.042 ; \mathrm{NH}_{4}{ }^{+} \mathrm{p}=\mathrm{p}<0.001 ;\right.$ Fig. $\left.2 \mathrm{~F}, \mathrm{G}\right)$. Water column $\mathrm{PO}_{4}{ }^{3-}$ was also significantly greater at $\mathrm{NC} 1$ $(p=0.008)$ and differed significantly over time with lowest values in early winter $(\mathrm{p}=0.008$; Fig. $2 \mathrm{H})$.

Sediment organic content and percentages of sand, silt and clay were the only sediment characteristics 

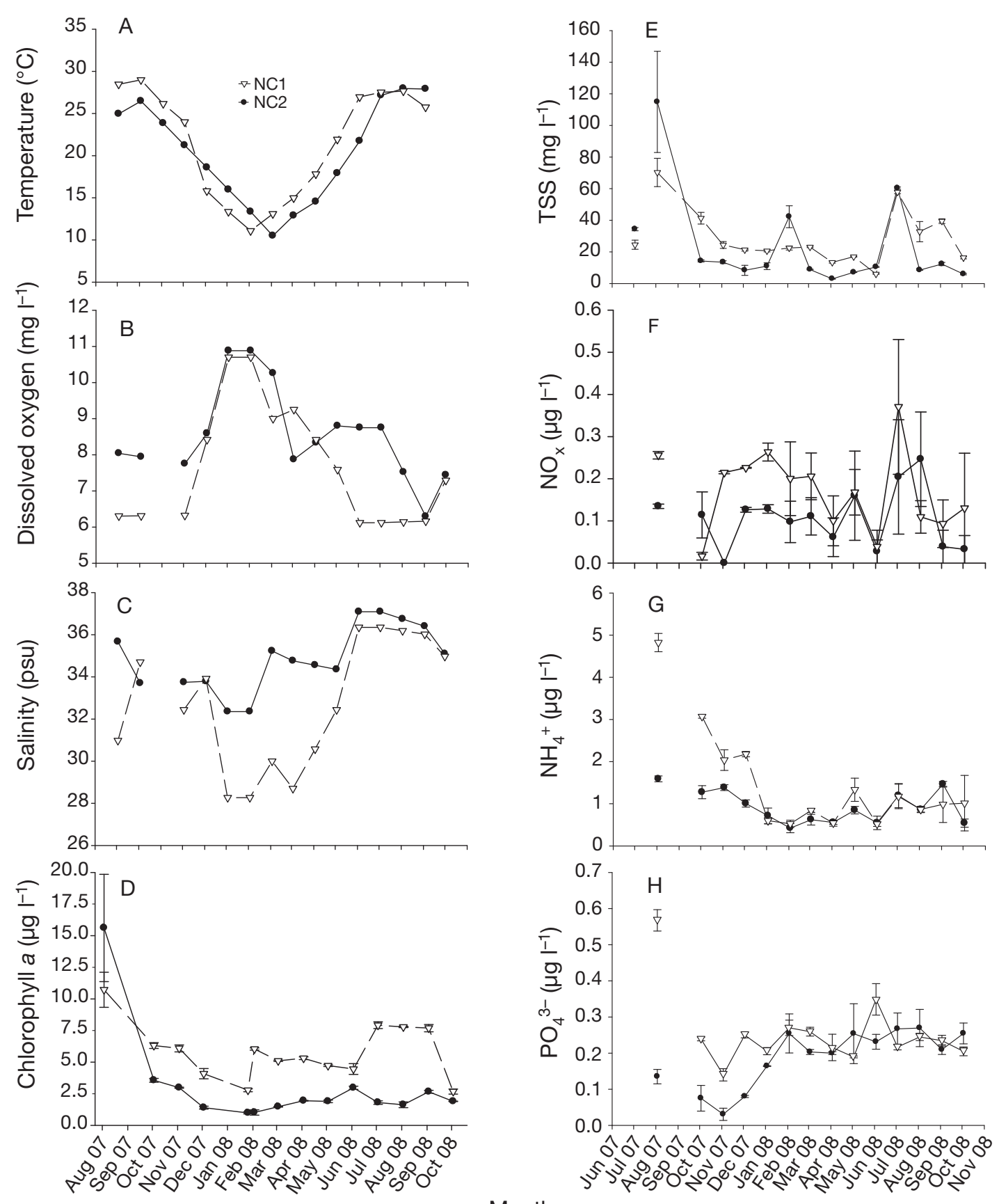

Fig. 2. Monthly values (mean $\pm \mathrm{SE} ; \mathrm{n}=3$ ) at 2 sites $(\mathrm{NC} 1$ and $\mathrm{NC} 2)$ in North Carolina for $(\mathrm{A})$ water temperatures $\left({ }^{\circ} \mathrm{C}\right) ;(\mathrm{B})$ dissolved oxygen $\left(\mathrm{mg} \mathrm{l}^{-1}\right) ;(\mathrm{C})$ salinity $(\mathrm{psu}) ;(\mathrm{D})$ chlorophyll a $\left(\mu \mathrm{gl}^{-1}\right) ;(\mathrm{E})$ total suspended solids $\left(\mathrm{TTS}_{;} \mathrm{mg} \mathrm{l}^{-1}\right) ;(\mathrm{F}) \mathrm{NO}_{\mathrm{x}}\left(\mu \mathrm{l}^{-1}\right)$; (G) $\mathrm{NH}_{4}{ }^{+}\left(\mu \mathrm{g} \mathrm{l}^{-1}\right)$; and $(\mathrm{H}) \mathrm{PO}_{4}{ }^{3-}\left(\mu \mathrm{g} \mathrm{l}^{-1}\right)$. Note differences in $y$-axes

to differ significantly between sites. NC1 had finer grained sediment composition (silt $\mathrm{p}=0.004$; clay $\mathrm{p}=$ 0.007; Table 1) and significantly greater sediment organic content $(\mathrm{p}<0.001)$ than NC2. Organic content did not change significantly over time $(\mathrm{p}=$ 0.789). Sediment $\mathrm{NH}_{4}{ }^{+}(\mathrm{p}=0.069)$ and $\mathrm{PO}_{4}{ }^{3-}(\mathrm{p}=$ 0.887 ) did not differ significantly between sites but did differ significantly over time ( $p<0.001$ for both).

\section{Zostera marina characterization}

There were no perennial plants at NC1 and all Zostera marina shoots originated from seedlings. At NC2, perennial plants surviving through summer contributed to population growth in the fall and in the next spring. There was no significant difference in vegetative aboveground biomass between sites $(\mathrm{p}=$ 


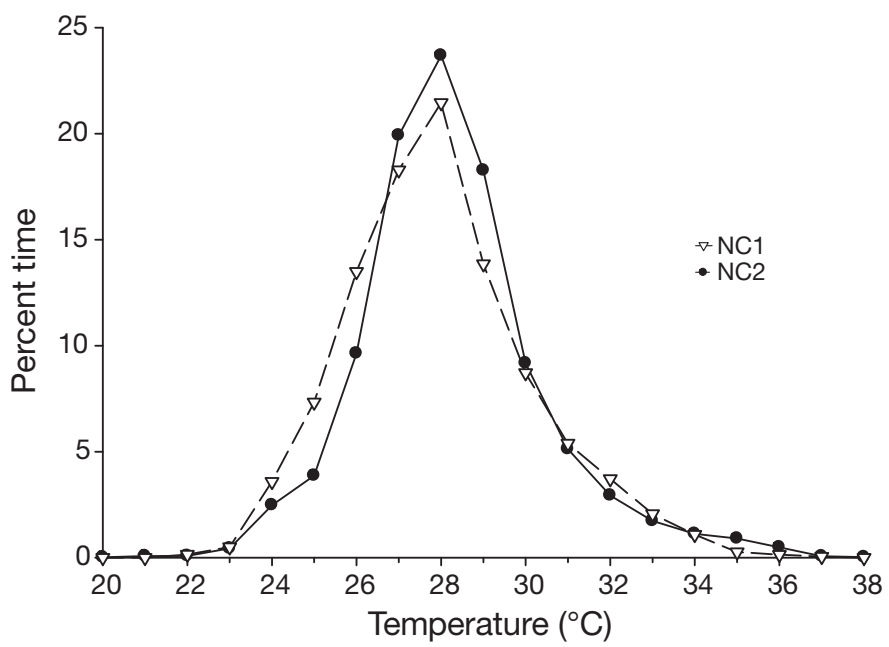

Fig. 3. Frequency distribution of 15-min water temperature measurements at 2 sites (NC1 and NC2) in North Carolina during June, July, and August 2008

0.648 ; Table 2A), although there was a difference over time $(\mathrm{p}<0.001$; Table 2A). Maximum aboveground vegetative biomass for both sites occurred in July in both 2007 and 2008 (Fig. 4A). Aboveground vegetative biomass (all values mean $\pm \mathrm{SE}$ ) was completely absent from NC1 in November 2007 and again in September and October 2008 while biomass decreased to the lowest recorded value, $13.80 \pm$ $5.00 \mathrm{~g} \mathrm{DW} \mathrm{m}^{-2}$, in October 2007 at NC2 (Fig. 4A).

Reproductive aboveground biomass at both sites varied over time $(\mathrm{p}<0.001$; Table $2 \mathrm{~A})$, reaching a maximum in March 2008 then decreasing until completely disappearing in July 2008 (Fig. 4B). Total reproductive shoot biomass and the proportion of reproductive to total shoot biomass was significantly greater at $\mathrm{NC} 1$ (maximum $30.93 \pm 2.41 \mathrm{~g} \mathrm{DW} \mathrm{m}^{-2}$ ) than NC2 (maximum $15.66 \pm 2.93 \mathrm{~g} \mathrm{DW} \mathrm{m}^{-2} ; \mathrm{p}=$ 0.003; Table 2A).
Belowground biomass was significantly greater at NC2 compared to NC1 $(p<0.001)$ and varied significantly over time $(\mathrm{p}<0.001$; Table $2 \mathrm{~B}$; Fig. 4C). Belowground biomass was completely absent November 2007 and reached a seasonal low in November 2008 at NC1 while reaching a seasonal

Table 2. Zostera marina. Results of repeated measures, ANOVA for biomass of (A) vegetative and reproductive shoots aboveground and (B) total belowground for 2 sites in North Carolina over the 2007-2008 growing season. ${ }^{*} \mathrm{p}<0.05$

\begin{tabular}{|c|c|c|c|c|c|}
\hline Factor & df & $\begin{array}{c}\text { Type III } \\
\text { SS }\end{array}$ & $\begin{array}{l}\text { Mean } \\
\text { SS }\end{array}$ & $\begin{array}{c}F \\
\text { value }\end{array}$ & $\mathrm{p}$ \\
\hline \multicolumn{6}{|c|}{ (A) Aboveground } \\
\hline \multicolumn{6}{|c|}{ Vegetative } \\
\hline \multicolumn{6}{|l|}{ Between Sites } \\
\hline Site & 1 & 0.11 & 0.11 & 0.22 & 0.648 \\
\hline Error (site) & 8 & 4.04 & 0.51 & & \\
\hline \multicolumn{6}{|l|}{ Within Sites } \\
\hline Time & 15 & 291.19 & 19.41 & 31.58 & $<0.001^{*}$ \\
\hline Time $\times$ Site & 15 & 56.92 & 3.79 & 6.17 & $0.003^{*}$ \\
\hline Error (time) & 120 & 73.78 & 0.61 & & \\
\hline \multicolumn{6}{|l|}{ Reproductive } \\
\hline \multicolumn{6}{|l|}{ Between Sites } \\
\hline Site & 1 & 2.65 & 2.65 & 17.52 & $0.003^{*}$ \\
\hline Error (site) & 8 & 1.21 & 0.15 & & \\
\hline \multicolumn{6}{|l|}{ Within Sites } \\
\hline Time & 4 & 3.23 & 0.81 & 10.1 & $<0.001^{*}$ \\
\hline Time $\times$ Site & 4 & 0.83 & 0.21 & 2.59 & 0.055 \\
\hline Error (time) & 32 & 2.56 & 0.08 & & \\
\hline \multicolumn{6}{|c|}{ (B) Belowground } \\
\hline \multicolumn{6}{|c|}{ Total } \\
\hline \multicolumn{6}{|l|}{ Between Sites } \\
\hline Site & 1 & 30.79 & 30.7910 & 010 & $<0.001^{*}$ \\
\hline Error (site) & 4 & 0.12 & 0.03 & & \\
\hline \multicolumn{6}{|l|}{ Within Sites } \\
\hline Time & 15 & 20.06 & 1.40 & 26.51 & $<0.001^{*}$ \\
\hline Time $\times$ Site & 15 & 11.88 & 0.79 & 14.95 & $<0.001^{*}$ \\
\hline Error (time) & 60 & 3.18 & 0.05 & & \\
\hline
\end{tabular}

Table 1. Sediment data (monthly mean \pm SE) for 2 sites in North Carolina (NC1 and NC2)

\begin{tabular}{|c|c|c|c|c|c|c|}
\hline Site and date & $\%$ organic matter & $\mathrm{NH}_{4}{ }^{+}(\mu \mathrm{M})$ & $\mathrm{PO}_{4}{ }^{3-}(\mu \mathrm{M})$ & $\%$ sand & $\%$ silt & \% clay \\
\hline \multicolumn{7}{|l|}{ NC1 } \\
\hline Jul 2007 & $3.0 \pm 0.2$ & $14.7 \pm 2.9$ & $0.9 \pm 0.1$ & - & - & - \\
\hline Dec 2007 & $3.3 \pm 0.3$ & $8.9 \pm 2.9$ & $0.8 \pm 0.2$ & $79.7 \pm 1.0$ & $14.3 \pm 0.7$ & $6.0 \pm 0.5$ \\
\hline Jun 2008 & $3.5 \pm 0.8$ & $42.1 \pm 17.0$ & $0.9 \pm 0.3$ & - & - & - \\
\hline Sep 2008 & $2.8 \pm 0.1$ & $21.3 \pm 7.5$ & $0.2 \pm 0.1$ & - & - & - \\
\hline \multicolumn{7}{|l|}{ NC2 } \\
\hline Jul 2007 & $1.3 \pm 0.1$ & $20.4 \pm 6.4$ & $1.5 \pm 0.5$ & - & - & - \\
\hline Dec 2007 & $1.3 \pm 0.2$ & $12.7 \pm 0.8$ & $0.6 \pm 0.2$ & $90.6 \pm 1.9$ & $6.5 \pm 1.4$ & $3.0 \pm 0.5$ \\
\hline Jun 2008 & $0.7 \pm 0.1$ & $15.2 \pm 1.6$ & $3.8 \pm 1.2$ & - & - & - \\
\hline Sep 2008 & $1.2 \pm 0.2$ & $14.3 \pm 2.4$ & $0.0 \pm 0.0$ & - & - & - \\
\hline
\end{tabular}


low in October 2007 and November 2008 at NC2 (Fig. 4C). The proportion of belowground biomass to total biomass was also greater at NC2 compared to NC1.

Vegetative shoot density was 2.5 times greater at NC2 than NC1 throughout the study period ( $\mathrm{p}<$
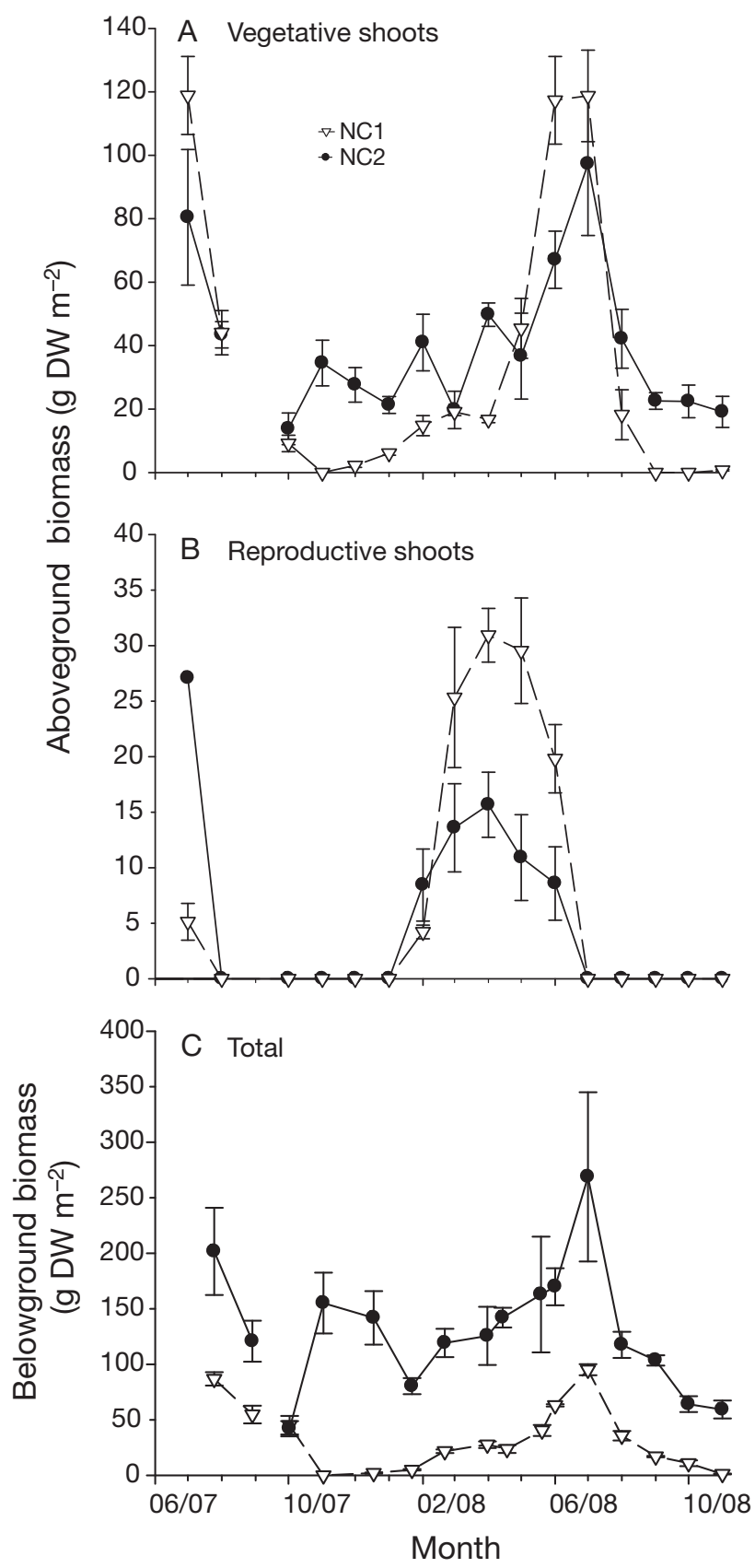

Fig. 4. Zostera marina. Monthly biomass at 2 sites (NC1 and NC2) in North Carolina. (A) Aboveground vegetative shoots; (B) aboveground reproductive shoots; and (C) belowground biomass (both vegetative and reproductive) during the 2007 to 2008 growing season. Means \pm SE $(n=5)$
0.001; Table 3). NC1 maximum abundance occurred in February, then decreased over time resulting in a complete loss of shoots after September 2008. Density increased again with germination of new seedlings in November 2008. NC2 maximum vegetative shoot density occurred in April, 2 mo later than at NC1. While exhibiting seasonal declines, Zostera marina density at NC2 was never below $531 \pm 248$ shoots $\mathrm{m}^{-2}$ (Fig. 5A).

Reproductive shoot densities were similar between sites ( $p=0.889$; Table 3 ). NC1 flowering shoot density reached a maximum in March 2008 (603 \pm 157 reproductive shoots $\mathrm{m}^{-2}$; Fig. 5B), while NC2 density peaked in May $2008\left(463 \pm 224\right.$ shoots $\left.\mathrm{m}^{-2}\right)$. The proportion of reproductive shoots, ranged from $33 \pm 3 \%$ at NC1 to $26 \pm 13 \%$ at NC2 of total shoots during the period of maximum reproductive shoot density (March to May 2008; Fig. 5C).

\section{Seed production and seed bank characteristics}

The average number of rhipidia per reproductive shoot, the number of seeds per rhipidia, and the potential seed production per area were similar between sites (Tables $3 \& 4$ ). Although not significantly different, potential seed production was numerically greater at NC1 (61563 seeds $\mathrm{m}^{-2}$ ) compared to NC2 (41146 seeds $\mathrm{m}^{-2}$ ). This is reflected in the seed bank were total density was 3.4 times greater at NC1 than NC2 ( $p<0.0001$; Table 3). Seeds were always present in the sediment at both sites, although $<1 \%$ of the estimated seeds produced in 2008 were retained within the sediment seed bank at NC2 and $<2 \%$ were retained in NC1. Seed bank viability was variable, but on average, densities of viable seeds were 27.2 times greater at NC1 than NC2 ( $p=0.003$; Table 3 ). No viable seeds were observed in the seed bank following the period of maximum germination (Table 5).

\section{DISCUSSION}

\section{Life history strategies}

Different Zostera marina populations have been characterized as either perennial, biennial, or annual forms (Setchell 1929, Keddy \& Patriquin 1978, Thayer et al. 1984). An alternative model was described for $Z$. marina in the southwestern Netherlands where a bed with attributes of both perennial and annual life histories was documented 
Table 3. Zostera marina. Negative binomial regression model analyzing the effects of site on vegetative shoot density, reproductive shoot density, maximum estimated number of produced seeds $\left(\mathrm{N}_{\mathrm{ps}}\right)$, total seed bank density $\left(\mathrm{N}_{\mathrm{sb}}\right)$, and viable seed bank density $\left(\mathrm{N}_{\mathrm{vb}}\right)$. Odds ratios calculated based on the parameter estimates. ${ }^{*} \mathrm{p}<0.05$

\begin{tabular}{|c|c|c|c|c|c|c|c|c|}
\hline \multirow[t]{2}{*}{ Parameter } & \multirow[t]{2}{*}{$\mathrm{df}$} & \multirow[t]{2}{*}{ Est } & \multirow[t]{2}{*}{$\mathrm{SE}$} & \multirow[t]{2}{*}{$\mathrm{X}^{2}$} & \multirow[t]{2}{*}{$\mathrm{p}$} & \multirow[t]{2}{*}{ Odds ratio } & \multicolumn{2}{|c|}{ Wald $95 \%$ CL } \\
\hline & & & & & & & Low & High \\
\hline \multicolumn{9}{|l|}{ Vegetative } \\
\hline Intercept & 1 & 4.28 & 0.08 & 2745.61 & $<0.001^{*}$ & & & \\
\hline Site & 1 & -0.9 & 0.12 & 56.95 & $<0.001^{*}$ & 0.41 & 0.32 & 0.51 \\
\hline Dispersion & 1 & 0.47 & 0.06 & & & & & \\
\hline \multicolumn{9}{|c|}{ Reproductive } \\
\hline Intercept & 1 & 2.43 & 0.17 & 214.88 & $<0.001^{*}$ & & & \\
\hline Site & 1 & 0.03 & 0.22 & 0.02 & 0.889 & 1.03 & 0.67 & 1.58 \\
\hline Dispersion & 1 & 0.51 & 0.11 & & & & & \\
\hline \multicolumn{9}{|l|}{$\mathbf{N}_{\mathrm{ps}}$} \\
\hline Intercept & 1 & 5.61 & 0.23 & 600.26 & $<0.001^{*}$ & & & \\
\hline Site & 1 & 0.54 & 0.32 & 2.84 & 0.092 & 1.72 & 3 & 246.53 \\
\hline Dispersion & 1 & 1.25 & 0.21 & & & & & \\
\hline \multicolumn{9}{|l|}{$\mathbf{N}_{\mathbf{s b}}$} \\
\hline Intercept & 1 & 0.28 & 0.18 & 2.52 & 0.112 & & & \\
\hline Site & 1 & 1.22 & 0.23 & 29.78 & $<0.001^{*}$ & 3.42 & 2.2 & 5.31 \\
\hline Dispersion & 1 & 0.86 & 0.21 & & & & & \\
\hline \multicolumn{9}{|l|}{$\mathbf{N}_{\mathrm{vb}}$} \\
\hline Intercept & 1 & 4.23 & 1.05 & 16.14 & $<0.001^{*}$ & & & \\
\hline Site & 1 & 3.3 & 1.13 & 8.62 & $0.003^{*}$ & 27.18 & 3 & 246.53 \\
\hline Dispersion & 1 & 7.66 & 3.53 & & & & & \\
\hline
\end{tabular}

Table 4. Zostera marina. Sexual reproductive effort at sites NC1 and NC2 during the 2007 to 2008 growing season. Means \pm SE across all months when reproductive shoots were present (February to July)

\begin{tabular}{|lcc|}
\hline Sexual reproductive output & NC1 & NC2 \\
\hline No. of reproductive shoots $\mathrm{m}^{-2}$ & $330 \pm 51$ & $243 \pm 57$ \\
No. of rhipidia per shoot & $3.5 \pm 0.2$ & $3.5 \pm 0.4$ \\
No. of seeds per rhipidia & $11 \pm 1$ & $10 \pm 1$ \\
Maximum no. of seeds produced $\mathrm{m}^{-2}$ & $12699 \pm 1982$ & $8515 \pm 2003$ \\
\hline
\end{tabular}

life history. However, some seedlings produced only reproductive shoots, a characteristic of annual plants. In addition to the senescence of reproductive shoots in the late spring, there was a second complete loss of vegetative shoot biomass at $\mathrm{NC1}$ after just 1 growing season. After the loss of flowering shoots, the surviving plants continued to grow asexually, suggesting that the complete loss of suggesting that some populations exist with a continuum of strategies that include perennial and annual life histories as end members (van Lent \& Verschuurre 1994). Our observations in North Carolina suggest that the occurrence of a similar alternate life history strategy for $Z$. marina populations at the southern limit of the species' distribution in the western North Atlantic.

Within a previously described perennial Zostera marina bed at NC1 (Penhale 1977, Thayer et al. 1977, 1984), we documented a population with a combination of perennial and annual characteristics. Following a complete loss of biomass, the population was reestablished by seedlings. A portion of the newly established seedlings reproduced asexually through clonal growth, similar to populations with a perennial biomass in the fall was due to other factors (i.e. temperature, bioturbation). Thus the $Z$. marina population described at $\mathrm{NC} 1$ displayed a mixture of perennial and annual life histories which we characterized as a 'mixed-annual' life history strategy.

Table 5. Zostera marina. Seed bank density and percentage of viable seeds at sites $\mathrm{NC} 1$ and NC2. Means $\pm \mathrm{SE}$

\begin{tabular}{|llllc|}
\hline \multirow{2}{*}{ Date } & \multicolumn{3}{c}{ Density $\left(\mathrm{m}^{-2}\right)$} & \multicolumn{2}{c|}{$\%$ viable } \\
& NC1 & NC2 & NC1 & NC2 \\
& & & & \\
\hline Jul 2007 & $190 \pm 97$ & $211 \pm 74$ & $33 \pm 21$ & $13 \pm 13$ \\
Dec 2007 & $232 \pm 84$ & $211 \pm 100$ & $0 \pm 0$ & $0 \pm 0$ \\
Jun 2008 & $906 \pm 246$ & $147 \pm 42$ & $18 \pm 9$ & $0 \pm 0$ \\
Nov 2008 & $232 \pm 91$ & $147 \pm 26$ & $0 \pm 0$ & $0 \pm 0$ \\
\hline
\end{tabular}



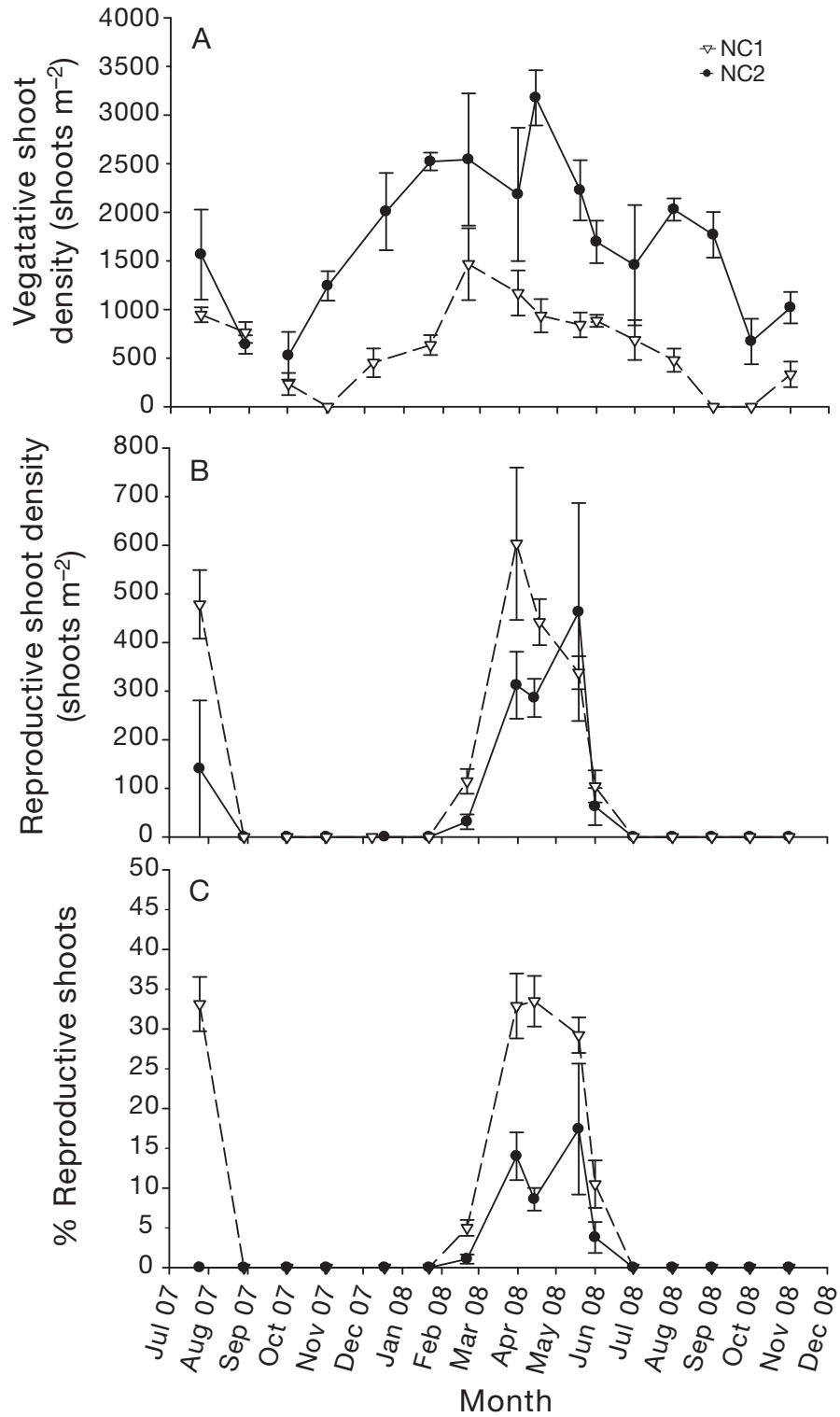

Fig. 5. Zostera marina. Monthly densities at 2 sites (NC1 and NC2) in North Carolina. (A) vegetative shoots, (B) reproductive shoots, (C) percentage of reproductive shoots. Means \pm $\mathrm{SE}(\mathrm{n}=5)$

\section{Attributes of a mixed-annual life history}

Zostera marina seedlings in the mixed-annual bed at NC1 flowered within 6 mo of germination. This was much earlier than perennial populations within the region which exhibit biennial characteristics and do not flower until their second year of growth (Silberhorn et al. 1983, Phillips et al. 1983b, Thayer et al. 1984). They also produced a greater number of flowering shoots per $\mathrm{m}^{-2}$ (maximum $603 \pm 157$ shoots $\mathrm{m}^{-2}$ ) than established perennial beds nearby at NC2 (79 \pm
110 to $463 \pm 224$ shoots $\mathrm{m}^{-2}$; Phillips et al. $1983 \mathrm{~b}$, this study). In addition, a larger proportion of reproductive shoots $(33 \pm 3 \%)$ were found in the mixedannual population compared to perennial beds $(<10$ to $28 \%$ of total shoots; Jacobs \& Pierson 1981, Silberhorn et al. 1983, Thayer et al. 1984, Olesen 1999). This is, however, significantly less than typical annual meadows where $100 \%$ of the shoots flower (Keddy \& Patriquin 1978, Robertson \& Mann 1984, Meling-López \& Ibarra-Obando 1999), and more similar to average densities of reproductive shoots produced in perennial populations.

The greater effort put into sexual reproduction in mixed-annual beds compared to perennial populations may come at the cost of bed maintenance and expansion through asexual reproduction. Energy necessary for vegetative expansion of Zostera marina is stored in non-structural carbohydrate reserves which are primarily found in the rhizomes (Burke et al. 1996). Belowground biomass (means $\pm \mathrm{SE}$ ) in the mixed-annual bed $\left(95.08 \pm 5.04 \mathrm{~g} \mathrm{DW} \mathrm{m}^{-2}\right)$ was significantly lower than perennial beds in North Carolina (268.81 $\pm 76.17 \mathrm{~g} \mathrm{DW} \mathrm{m}^{-2}$; Thayer et al. 1984) and in the lower Chesapeake Bay (155 $\mathrm{g} \mathrm{DW} \mathrm{m}^{-2}$; Orth \& Moore 1986) and more similar to annual populations observed in the Gulf of California at Punta Chueca (51 \pm 17 g DW m ${ }^{-2}$; Meling-López \& IbarraObando 1999) and in Bahía Concepción (26 g DW $\mathrm{m}^{-2}$; Santamaría-Gallegos et al. 2000). Robertson \& Mann (1984) hypothesized that the lower belowground biomass found in annual compared to perennial populations was related to the shorter development time in the abbreviated lifecycle of annual populations. Like annual beds, the mixed-annual bed NC1 grows for only a portion of the year and has less time to develop belowground biomass than perennial beds. More energy is allocated to the development of reproductive shoots resulting in a greater proportion of biomass in aboveground compared to belowground structures, mainly as flowers and seeds.

Survival of Zostera marina beds that die back annually is dependent on the production of flowers and viable seeds. The mixed-annual population yielded more seeds than the perennial site but had a lower maximum potential seed abundance (61563 seeds $\mathrm{m}^{-2}$ ) than reported in annual populations in Nova Scotia (78224 seeds $\mathrm{m}^{-2}$; Keddy 1987) and in the Sea of Cortez, Mexico (100376 seeds m² Meling-López \& Ibarra-Obando 1999). This reduced number of seeds may have severe negative consequences for true annual populations as the seed bank may not contain enough seeds to allow for a sufficient number of shoots to germinate and re-establish 
the bed. However, by reproducing both sexually and asexually newly germinated seedlings in the mixedannual bed may grow and become established more rapidly than seedlings which only produce reproductive shoots (Keddy \& Patriquin 1978; van Lent \& Verschuure 1994). Therefore, while seed production in mixed-annual beds is limited compared to annual populations, the ability to reproduce both sexually and asexually may compensate for the lack of seed material through relatively rapid expansion and establishment.

In areas with stressful environmental conditions, the production of a greater number of viable seeds may be more beneficial than maintaining year round biomass. This is especially important at the southern limit of Zostera marina distribution in North Carolina where water temperatures can exceed the upper limit of the optimum range of the species $\left(25^{\circ} \mathrm{C}\right)$ for a high percentage of July and August (Penhale 1977, Thayer et al. 1977, 1984). Water temperatures above $25^{\circ} \mathrm{C}$ can significantly reduce photosynthetic rates, increase respiration, inhibit leaf growth, and increase $Z$. marina mortality (Marsh et al. 1986, Nejrup \& Pedersen 2008, Hosokawa et al. 2009; Höffle et al. 2011). Large scale loss of perennial Z. marina populations in the Chesapeake Bay was attributed to stressful environmental conditions including water temperatures exceeding $30^{\circ} \mathrm{C}$ for only a few weeks in 2005 (Moore \& Jarvis 2008). Large scale seed germination and seedling establishment contributed to recovery in Chesapeake Bay (Jarvis \& Moore 2010), highlighting the importance of seeds for recovery from large scale declines (Plus et al. 2003, Greve et al. 2005, Lee et al. 2007).

In addition to seed production, another very important factor in considering the potential importance of the mixed-annual life history is the timing of flowering during the life cycle of the plants. Perennial populations that include plants with biennial characteristics do not flower until at least their second year of growth (Setchell 1929, Silberhorn et al. 1983, Thayer et al. 1984). Thus, when a biennial population experiences a high rate of mortality the potential for seed production in the next growing seasons is diminished. This population may be re-established by seeds produced during the previous growing season, but there may be few or no 'second year' biennial plants to produce flowers and replenish the seed bank. Since the seed bank is transient and can only be replenished by the production of new flowers, seed stocks will be even more depleted if there is a second stress event during the next growing season (Jarvis \& Moore 2010). Seed banks function to replenish populations annually and as a recovery mechanism following large scale disturbances (Plus et al. 2003, Greve et al. 2005, Jarvis \& Moore 2010). If the seed bank is depleted by consecutive years of stressful conditions resulting in large scale loss of biomass in perennial beds, this may result in the complete loss of the effected population (Jarvis \& Moore 2010). Populations expressing the mixedannual life history strategy have seedlings that are able to flower during their first year ensuring the seed bank is replenished with viable seeds. Therefore the mixed-annual population is able to persist in areas with stressful environmental conditions which may otherwise limit or exclude perennial populations.

Regardless of the strategy by which seeds are produced, they must remain viable in the sediment seed bank until conditions are favorable for germination, after which seedlings can replace adults within the established population (Baker 1989, Murdoch \& Ellis 2000). At NC1 and NC2 the seed bank density declined so that by the fall of 2008, following the period of maximum germination for this region (Silberhorn et al. 1983, Thayer et al. 1984), <2\% of that year's estimated seed production remained viable in the sediment. Similar large losses of seeds, ranging from 25 to $78 \%$ of total seed production, have been reported for both annual and perennial Zostera marina beds (Santamaría-Gallegos et al. 2000, Harwell \& Orth 2002b, Morita et al. 2007). These losses may be the result of dispersal (Harwell \& Orth 2002a, Källström et al. 2008), decay (Morita et al. 2007), predation (Fishman \& Orth 1996), or germination (Harper 1977).

The persistence of vegetative shoots after the senescence of reproductive shoots is another feature of the mixed-annual life history strategy that distinguishes it from annual populations. Annual populations of Zostera marina produce only reproductive shoots which senesce at the end of the flowering period (Keddy \& Patriquin, 1978, Gagnon et al. 1980, De Cock 1981, Harlin et al. 1982, Phillips et al. 1983a, Robertson \& Mann 1984, Santamaría-Gallegos et al. 2000). The complete loss of biomass and survival of the population in seed form may provide a mechanism to escape stressful environmental conditions via the seed bank (Phillips et al. 1983a, Robertson \& Mann 1984, van Lent \& Verschuure 1994, Santamaría-Gallegos et al. 2000). However, if stressful environmental conditions are ameliorated, annual beds are not capable of maintaining a population after the loss of reproductive shoots. The vegetative shoots in the mixed-annual population documented 
here continued to persist for up to 3 mo following the last observation of reproductive shoots. Vegetative reproduction by mixed-annual plants enables the population to perenniate and expand when the external factors responsible for mortality and complete loss of biomass are absent.

\section{SUMMARY AND CONCLUSIONS}

Growing near its southern range limit in the western North Atlantic, populations of Zostera marina express a range of life histories including both perennial and annual forms as well as a combination of both strategies. A mixed-annual life history described for NC1 illustrates an alternate mechanism for persistence through both short-term and extended periods of environmental stress. Reproducing both sexually and asexually during the first year of growth maximizes inter-annual survival of $Z$. marina populations by ensuring maintenance of the existing bed through clonal propagation as well as providing a source of seeds to replenish the population the next growing season (Table 6). We hypothesize that the mixed-annual life history improves the probability for Z. marina populations to persist in stressful environments. Rather than relying on a single life history strategy, some populations in North Carolina can use a range of strategies to overcome the high rate of mortality in a thermally stressed environment.

We suggest that neither annual nor perennial or biennial life history strategies always provide a superior mechanism for population persistence. For example, perennial meadows are able to maintain their populations with clonal reproduction, but are susceptible to multiple consecutive years of large scale loss due to a lack of viable seed bank replenishment (Jarvis \& Moore 2010; Table 6). Annual meadows are able to overcome stressful environmental conditions through the annual production of reproductive shoots and a viable seed bank, but these populations are not able to fully exploit available resources throughout the entire growing season due to a lack of vegetative reproduction (Keddy \& Patriquin 1978, Phillips et al. 1983a, Hootsmans et al. 1987, Meling-López \& Ibarra-Obando, 1999; Table 6). Zostera marina is a species that has evolved over millions of years in ephemeral coastal environments (Les et al. 1997, Waycott et al. 2006) and we hypothesize that the species has developed a variety of life history strategies that range between perennial and annual depending on environmental conditions.

Seagrass meadows are being lost from coastal ecosystems at a global rate of $110 \mathrm{~km}^{2} \mathrm{yr}^{-1}$ (Waycott et al.

Table 6. Zostera marina. Description of life history strategies expressed in beds near the species' southern limit in the western North Atlantic under both stressed and non-stressed conditions. For this table, stress is assumed to occur at the end of the growing season after flowers have senesced and seeds have been produced

\begin{tabular}{|c|c|c|c|}
\hline Life history & Year 1 & Year 2 & Year 3 \\
\hline \multicolumn{4}{|l|}{ Stress } \\
\hline Perennial & $\begin{array}{l}\text { All plants die; viable seeds in } \\
\text { seed bank from previous year } \\
\text { flowering }\end{array}$ & $\begin{array}{l}\text { Bed recovers from seedlings; within year all } \\
\text { plants die; no viable seeds remain in seed bank }\end{array}$ & No bed recovery \\
\hline Annual & $\begin{array}{l}\text { All plants die; viable seeds } \\
\text { remain in seed bank from } \\
\text { previous year flowering }\end{array}$ & $\begin{array}{l}\text { Bed recovers from seedlings; flowers; within year } \\
\text { all plants die; viable seeds remain in seed bank }\end{array}$ & $\begin{array}{l}\text { Bed recovers from } \\
\text { seedlings and persists }\end{array}$ \\
\hline $\begin{array}{l}\text { Mixed- } \\
\text { annual }\end{array}$ & $\begin{array}{l}\text { All plants die; viable seeds } \\
\text { remain in seed bank from } \\
\text { previous year flowering }\end{array}$ & $\begin{array}{l}\text { Bed recovers from seedlings; flowers; within year } \\
\text { all plants die; viable seeds remain in seed bank }\end{array}$ & $\begin{array}{l}\text { Bed recovers from } \\
\text { seedlings and persists }\end{array}$ \\
\hline \multicolumn{4}{|l|}{ No stress } \\
\hline Perennial & $\begin{array}{l}\text { Plants persist; viable seeds } \\
\text { in seed bank from previous } \\
\text { year flowering }\end{array}$ & $\begin{array}{l}\text { Bed persists from vegetative growth and } \\
\text { seedlings; flowers; plants persist; viable seeds } \\
\text { remain in seed bank }\end{array}$ & $\begin{array}{l}\text { Bed persists from } \\
\text { largely vegetative }\end{array}$ \\
\hline Annual & $\begin{array}{l}\text { All plants die; viable seeds } \\
\text { remain in seed bank from } \\
\text { previous year flowering }\end{array}$ & $\begin{array}{l}\text { Bed re-grows from seedlings; flowers; all plants } \\
\text { die; viable seeds remain in seed bank }\end{array}$ & $\begin{array}{l}\text { Bed recovers from } \\
\text { seedlings and persists }\end{array}$ \\
\hline $\begin{array}{l}\text { Mixed- } \\
\text { annual }\end{array}$ & $\begin{array}{l}\text { Annual plants die; viable } \\
\text { seeds in seed bank from } \\
\text { previous year flowering }\end{array}$ & $\begin{array}{l}\text { Bed persists from vegetative growth and } \\
\text { seedlings; flowers; annual plants die; viable seeds } \\
\text { remain in seed bank }\end{array}$ & $\begin{array}{l}\text { Bed persists from } \\
\text { vegetative growth } \\
\text { and seedlings }\end{array}$ \\
\hline
\end{tabular}


2009) and are predicted to continue declining as conditions become increasingly stressful due to global climate change (Short \& Neckles 1999, Harley et al. 2006). This period of unprecedented environmental transition may result in large scale shifts in the distribution of species (Rogers \& McCarty 2000, Scavia et al. 2002) and, in the most extreme cases, greater mortality of sensitive species at local and regional levels (Rogers \& McCarty 2000, Najjar et al. 2010). The mixed-annual life history described here represents one possible life history strategy within this range, which may provide the mechanism necessary for Zostera marina populations to persist during times of environmental transition. Understanding how the life history strategies of seagrasses may affect their distribution and persistence of a species on local and regional scales is vital for effective prediction of responses to environmental and anthropogenic stressors and ultimately the management of these coastal resources.

Acknowledgements. The authors would like to thank the National Estuarine Research Reserve Graduate Research Fellowship Program and the Virginia Institute of Marine Science Graduate Research Assistantship Program for funding. Field and laboratory support was provided by the Center for Coastal Fisheries and Habitat Research. We would also like to thank Erin Shields, Brittany Haywood, Giuseppe Di Carlo, Brooke Landry, and Brandon Jarvis for field and laboratory assistance. This is contribution number 3183 from the Virginia Institute of Marine Science, School of Marine Science, College of William and Mary.

\section{LITERATURE CITED}

Allison PD (1999) Logistic Regression Using the SAS System: Theory and Application. SAS Institute Inc., Cary NC Association of Official Seed Analysts (AOSA) (1981) Rules for testing seeds. J Seed Tech 6:1-126

Baker HG (1989) Some aspects of the natural history of seedbanks. In: Leck MA, Parker VT, Simpson RL (eds) Ecology of soil seed banks. Academic Press, San Diego, CA, p 9-21

Burke MK, Dennison WC, Moore KA (1996) Non-structural carbohydrate reserves of eelgrass Zostera marina. Mar Ecol Prog Ser 137:195-201

Conacher CA, Poiner IR, Butler J, Pun S, Tree DJ (1994) Germination, storage and viability testing of seeds of Zostera capricorni Aschers. from a tropical bay in Australia. Aquat Bot 49:47-58

De Cock AWAM (1981) Development of the flowering shoot of Zostera marina L. under controlled conditions in comparison to the development in two different natural habitats in the Netherlands. Aquat Bot 10:99-113

den Hartog C (1970) The Sea-grasses of the world. NorthHolland, Amsterdam

Erftemeijer PLA, Koch EW (2001) Sediment geology methods for seagrass habitat. In: Short FT, Coles RG (eds)
Global seagrass research methods. Elsevier Science, Amsterdam, p 345-367

Fishman JR, Orth RJ (1996) Effects of predation on Zostera marina L. seed abundance. J Exp Mar Biol Ecol 198: $11-26$

Fonseca MS, Kenworthy WJ, Thayer GW, Heller DY, Cheap KM (1985) Transplanting of the seagrasses Zostera marina and Halodule wrightii for sediment stabilization and habitat development on the east coast of the United States. Technical Report EL-85-9, US Army Corps of Engineers, Waterways Experiment Station, Vicksburg, MS

Gagnon PS, Vadas RL, Burdick DB, May B (1980) Genetic identity of annual and perennial forms of Zostera marina L. Aquat Bot 8:157-162

Green EP, Short FT (2003) World atlas of seagrasses. University of California Press, Berkley, CA

Greve TM, Krause-Jensen D, Rasmussen MB, Christensen PB (2005) Means of rapid eelgrass (Zostera marina L.) recolonization in former dieback areas. Aquat Bot 82: $143-156$

> Harley CDG, Hughes AR, Hultgren KM, Miner BG and others (2006) The impacts of climate change in coastal marine systems. Ecol Lett 9:228-241

> Harlin MM, Thorne-Miller B, Boothroyd JC (1982) Seagrasssediment dynamics of a flood-tidal delta in Rhode Island (USA). Aquat Bot 14:127-138

Harper JL (1977) Population biology of plants. Academic Press, London.

$>$ Harrison PG (1993) Variations in demography of Zostera marina and $Z$. noltii on an intertidal gradient. Aquat Bot 45:63-77

> Harwell MC, Orth RJ (2002a) Long-distance dispersal potential in a marine macrophyte. Ecology 83:3319-3330

> Harwell MC, Orth RJ (2002b) Seed bank patterns in Chesapeake Bay eelgrass (Zostera marina L.): a bay-wide perspective. Estuaries 25:1196-1204

> Höffle H, Thomsen MS, Holmer M (2011) High mortality of Zostera marina under high temperature regimes but minor effects of the invasive macroalgae Gracilaria vermiculophylla. Estuar Coast Shelf Sci 92:35-46

> Hootsmans MJM, Vermaat JE, Van Vierssen W (1987) Seed bank development, germination, and early seedling survival of two seagrass species from the Netherlands: Zostera marina L. and Zostera noltii Hornem. Aquat Bot 28:275-285

Hosokawa S, Nakamura Y, Kuwae T (2009) Increasing temperature induces shorter leaf life span in an aquatic plant. Oikos 118:1158-1163

> Jacobs RPWM, Pierson ES (1981) Phenology of reproductive shoots of eelgrass, Zostera marina L., at Roscoff (France). Aquat Bot 10:45-60

$>$ Jarvis JC, Moore KA (2010) The role of seedlings and seed bank viability in the recovery of Chesapeake Bay, USA, Zostera marina populations following a large-scale decline. Hydrobiologia 649:55-68

Källström B, Nyqvist A, Åberg P, Bodin M, André C (2008) Seed rafting as a dispersal strategy for eelgrass (Zostera marina). Aquat Bot 88:148-153

- Keddy CJ (1987) Reproduction of annual eelgrass variation among habitats and comparison with perennial eelgrass (Zostera marina L.). Aquat Bot 27:243-256

$>$ Keddy CJ, Patriquin DG (1978) An annual form of eelgrass in Nova Scotia. Aquat Bot 5:163-170

Kenworthy WJ (1981) The interrelationship between sea- 
grasses, Zostera marina and Halodule wrightii, and the physical and chemical properties of sediments in a midAtlantic coastal plain estuary near Beaufort, North Carolina (USA). MS thesis, University of Virginia, Charlottesville, VA

Knepel K, Bogren K (2002). Determination of orthophosphate by flow injection analysis. QuikChem Method 31-11501-1-H (revised edn). Lachat Instruments, Milwaukee, WI

Lakon G (1949) The topographical tetrazolium method for determining the germinating capacity of seeds. Plant Physiol 24:389-394

> Lee KS, Park JI, Kim YK, Park SR, Kim JH (2007) Recolonization of Zostera marina following destruction caused by red tide algal bloom: the role of new shoot recruitment from seed banks. Mar Ecol Prog Ser 342:105-115

Les DH, Cleland MA, Waycott M (1997) Phylogenetic studies in Alismatida. II. Evolution of marine angiosperms (seagrasses) and hydrophily. Syst Bot 22:443-463

Liao N (2002) Determination of ammonia in brackish or seawater by flow injection analysis. QuikChem Method 31-107-06-1-B (revised edn). Lachat Instruments, Milwaukee, WI

Lincoln RJ, Boxshall GA, Clark PF (1990) A dictionary of ecology, evolution, and systematics. Cambridge University Press, New York, NY

Marsh JA Jr, Dennison WC, Alberte RS (1986) Effects of temperature on photosynthesis and respiration in eelgrass (Zostera marina L.). J Exp Mar Biol Ecol 101: 257-267

McFarland DG, Shafer DJ (2011) Protocol consideration for aquatic plant seed bank assessment. J Aquat Plant Manage 49:9-19

> Meling-López AE, Ibarra-Obando SE (1999) Annual life cycles of two Zostera marina L. populations in the Gulf of California: contrasts in seasonality and reproductive effort. Aquat Bot 65:59-69

Moore KA, Jarvis JC (2008) Environmental factors affecting recent summertime eelgrass diebacks in the Lower Chesapeake Bay: implications for long-term persistence. J Coast Res 55(Spec Iss):135-147

Moore KA, Short FT (2006) Zostera: biology, ecology, and management. In: Larkum AWD, Orth RJ, Duarte CM (eds) Seagrasses: biology, ecology, and conservation. Springer Dordrecht, p 361-386

- Morita T, Okumura H, Abe M, Kurashima A, Maegawa M (2007) Density and distribution of seeds in bottom sediments in Zostera marina beds in Ago Bay, central Japan. Aquat Bot 87:38-42

Murdoch AJ, Ellis RM (2000) Dormancy, viability and longevity. In: Fenner M (ed) Seeds: the ecology of regeneration in plant communities, 2nd edn. CAB International, Wallingford, p 183-214

> Najjar RG, Pyke CR, Adams MB, Breitburg D and others (2010) Potential climate-change impacts on the Chesapeake Bay. Estuar Coast Shelf Sci 86:1-20

Nejrup LB, Pedersen MF (2008) Effects of salinity and water temperature on the ecological performance of Zostera marina. Aquat Bot 88:239-246

> Olesen B (1999) Reproduction in Danish eelgrass (Zostera marina L.) stands: size-dependence and biomass partitioning. Aquat Bot 65:209-219

Orth RJ, Moore KA (1986) Seasonal and year-to-year variations in the growth of Zostera marina L. (eelgrass) in the lower Chesapeake Bay. Aquat Bot 24:335-341

Penhale PA (1977) Macrophyte-epiphyte biomass and pro- ductivity in an eelgrass (Zostera marina L.) community. J Exp Mar Biol Ecol 26:211-224

Phillips RC, Backman TW (1983) Phenology and reproductive biology of eelgrass (Zostera marina L.) at Bahia Kino, Sea of Cortez, Mexico. Aquat Bot 17:85-90

Phillips RC, Grant WS, McRoy CP (1983a) Reproductive strategies of eelgrass (Zostera marina) L. Aquat Bot 16: $1-20$

Phillips RC, McMillan C, Bridges KW (1983b) Phenology of eelgrass, Zostera marina L., along latitudinal gradients in North America. Aquat Bot 15:145-156

Plumb RH Jr (1981) Procedures for handling and chemical analysis of sediment and water samples. Technical Report EPA/CE-81-1, US Army Corps of Engineers, Waterways Experiment Station, Vicksburg, MS

Plus MJ, Deslous-Paoli M, Dagault F (2003) Seagrass (Zostera marina L.) bed recolonization after anoxiainduced full mortality. Aquat Bot 77:121-134

Robertson AI, Mann KH (1984) Disturbance of ice and lifehistory adaptations of the seagrass Zostera marina. Mar Biol 80:131-141

> Rogers CA, McCarty JP (2000) Climate change and ecosystems of the Mid-Atlantic Region. Clim Res 14:235-244

Santamaría-Gallegos NA, Sánchez-Lizaso JL, Félix-Pico EF (2000) Phenology and growth cycle of annual subtidal eelgrass in a subtropical locality. Aquat Bot 66:329-339

Scavia D, Field JC, Boesch DF, Buddemeier DF and others (2002) Climate change impacts on US coastal and marine ecosystems. Estuaries 25:149-164

Setchell WA (1929) Morphological and phonological notes on Zostera marina L. Univ Calif Pub Bot 14:389-452

> Short FT, Neckles HA (1999) The effects of global climate change on seagrasses. Aquat Bot 63:169-196

Silberhorn GM, Orth RJ, Moore KA (1983) Anthesis and seed production in Zostera marina L. (eelgrass) from the Chesapeake Bay. Aquat Bot 15:133-144

Smith P, Bogren K (2002) Determination of nitrate and/or nitrite in brackish or seawater by flow injection analysis colorimetry. QuikChem Method 31-107-04-1-E (revised edn). Lachat Instruments, Milwaukee, WI

Solorzano L (1969) Determination of ammonia in natural waters by the phenol hypochlorite method. Limnol Oceanogr 14:799-801

Street MW, Deaton AS, Chappell WS, Mooreside PD (2005) North Carolina Coastal Habitat Protection Plan. North Carolina Department of Environment and Natural Resources, Division of Marine Fisheries, Morehead City, NC

Strickland J, Parsons T (1972) A practical handbook of seawater analysis, 2nd edn. Bull Fish Res Board Can 167: $1-311$

- Taylor ARA (1957a) Studies of the development of Zostera marina L. I. The embryo and seed. Can J Bot 35:477-499

Taylor ARA (1957b) Studies of the development of Zostera marina L. II. Germination and seedling development. Can J Bot 35:681-695

Thayer GW, Engel DW, LaCroix MW (1977) Seasonal distribution and changes in the nutritive quality of living, dead, and detrital fraction of Zostera marina L. J Exp Mar Biol Ecol 30:109-127

Thayer GA, Kenworthy WJ, Fonseca KS (1984) The ecology of eelgrass meadows of the Atlantic coast: a community profile. FWS/OBS-84, US Fish and Wildlife Service, Washington, DC

Tomlinson PB (1974) Vegetative morphology and meristem dependence-The foundation of productivity in sea- 
grasses. Aquaculture 4:107-130

van Katwijk MM, Wijgergangs LJM (2004) Effects of locally varying exposure, sediment type and low-tide water cover on Zostera marina recruitment from seed. Aquat Bot 80:1-12

van Lent F, Verschuure JM (1994) Intraspecific variability of Zostera marina L. (eelgrass) in the estuaries and lagoons of the southwestern Netherlands. II. Relation to environmental factors. Aquat Bot 48:59-75

Waycott M, Procaccini G, Les DH, Reusch TBH (2006) Sea-

Editorial responsibility: William Kemp,

Cambridge, Maryland, USA grass evolution, ecology and conservation: a genetic perspective. In: Larkum AWD, Orth RJ, Duarte CM (eds) Seagrasses: biology, ecology, and conservation. Springer Dordrecht, p 25-50

- Waycott M, Duarte CM, Carruthers TJB, Orth RJ and others (2009) Accelerating loss of seagrasses across the globe threatens coastal ecosystems. Proc Natl Acad Sci USA 106:12377-12381

Zar JH (1996) Bio-statistical analysis, 3rd edn. Prentice Hall, London

Submitted: March 28, 2011; Accepted: September 30, 2011 Proofs received from author(s): December 14, 2011 